\title{
Microstructure and Mechanical Properties Analysis of Quenched and Tempered AISI 4340 Steel
}

\section{Imam Basori ${ }^{1}$, Almalia Surocaena ${ }^{1}$, Siska Titik Dwiyati ${ }^{1}$, Yunita Sari ${ }^{1}$, and Balbir Sing ${ }^{2}$}

${ }^{1}$ Department of Mechanical Engineering, Faculty of Engineering, Universitas Negeri Jakarta, J. Rawamangun Muka, Jakarta 13220, Indonesia

${ }^{2}$ Department of Mechanical Engineering, S M V D U, Katra 182320, J\&K, India

\section{Abstract}

This research was conducted to determine the optimum parameters in quenching and tempering processes of AISI 4340 steel. Quenching and tempering processes were carried out to modify the microstructure and mechanical properties, especially to achieve the high strength and toughness resilience for steel armor application. Steel is widely use as armor material due to its ease processing, lower production costs,

Corresponding Author: Imam Basori

unimam_r_one@yahoo.com

Received: 11 January 2019

Accepted: 14 February 2019

Published: 25 March 2019

Publishing services provided by Knowledge E

(c) Imam Basori et al. This article is distributed under the terms of the Creative Commons

Attribution License, which permits unrestricted use and redistribution provided that the original author and source are credited.

Selection and Peer-review under the responsibility of the 3rd ICTVET 2018 Conference Committee.

\section{G OPEN ACCESS}

high strength, good toughness, and heat treatment capabilities. This material has also a reasonable price and good availability. Metallurgical structure becomes a crucial factor, especially for ballistic-resistant vehicle applications. The samples of AISI 4340 commercial steel with dimension of $55 \times 10 \times 10 \mathrm{~mm}^{3}$ were austenized at temperature of $800{ }^{\circ} \mathrm{C}$ for 1 and $2 \mathrm{~h}$ in a muffle furnace and followed by quenching process with oil as the media. Furthermore, the quenched samples were then tempered at $300^{\circ} \mathrm{C}$ for 2, 3, and $4 \mathrm{~h}$ at the muffle furnace as well. Microstructure analysis was conducted by using optical microscopes. The result showed that quenching process promoted the phase transformation from the combination of ferrite and pearlite to be the ferrite and martensite with the shape like a needle. On the other hand, the tempering process promotes the transformation of martensite to bainite. Quenching has also led to increasing of hardness.

Keywords: AISI 4340, quenching, tempering, martensite.

\section{Introduction}

Armor materials are designed to hold the bullet penetration and others, in which the metallurgical structures become the crucial factor. This material has also designed to be able to break and hold projectiles fired at high velocity [1, 2] due to the good hardness and impact resilience [3, 4]. The kinds of armor materials used for military applications are steel, ceramics, polymers, and composites [5], although steel is the most widely used due to its ease processing, lower production costs, high strength, good toughness, and 
heat treatment capabilities [6]. Steel armor has also well known as the bullet resistant steel in regard with its application as the protective material for civilian and military vehicles [7]. The mechanical properties of steel can be improved by the heat treatment process.

Previous research showed that the heat treatment process was conducted on AR500 [8] steel, 4140 steel [9] and PROTAC 500 steel [10] with the temperature of quenching and tempering between $800-900{ }^{\circ} \mathrm{C}$ and $200-300{ }^{\circ} \mathrm{C}$, respectively. This treatment was aimed to improve the physical and mechanical properties, which they heavily depend on optimum temperature, holding time, and also the cooling process. The experiment showed that the microstructure was dominated by martensite and bainite phases and the materials have capability to hold the ballistic loads with the thickness plate above $7 \mathrm{~mm}$. This phenomenon showed that the good ballistic resilience was achieved at a fairly high thickness and resulted in high sample mass which the characteristic is not appropriate for armored vehicle application that requires lower weight to reach a high mobility. This research was intended to comprehend the effect of quenching and tempering process on the microstructure, hardness, and impact properties of AISI 4340 steel. The experiment is expected to produce the better physical and mechanical properties.

\section{Methods and Equipment}

The samples of AISI 4340 commercial steel with dimension of $55 \times 10 \times 10 \mathrm{~mm}^{3}$ were austenized at temperature of $800{ }^{\circ} \mathrm{C}$ for 1 and $2 \mathrm{~h}$ in a muffle furnace and followed by quenching process with media of oil. The composition of the steel is shown in Table 1. Furthermore, the quenched samples were then tempered at $300^{\circ} \mathrm{C}$ for 2,3 , and $4 \mathrm{~h}$ at the muffle furnace as well. Microstructure analysis was conducted by using optical microscopes. Previously, the samples were mechanically grounded by abrasive paper and polished by metal polish followed by etching with $\mathrm{HNO} 30.4 \%$ in alcohol in accordance with ASTM E407:2007. The hardness and impact testing were conducted by Vickers and Charpy methods, respectively.

TABLE 1: Nominal composition of the AISI 4340 steel.

\begin{tabular}{|l|c|c|c|c|c|c|c|}
\hline C & $\mathrm{Mn}$ & $\mathrm{P}$ & $\mathrm{S}$ & $\mathrm{Ni}$ & $\mathrm{Cr}$ & $\mathrm{Mo}$ & $\mathrm{V}$ \\
\hline 0.3 & 0.3 & 0.025 & 0.4 & 0.5 & 0.4 & 0.15 & 0.15 \\
\hline
\end{tabular}




\section{Results and Discussion}

\subsection{Microstructures}

Figure.1 (a-c) shows the microstructure of the samples; before and after quenching process. As shown in Figure.1a, the microstructure of raw material is dominated by the ferrite and pearlite phases. The quenching process promoted the phase transformation from the combination of ferrite and pearlite to be the ferrite and martensite with the shape like a needle (Figure. $1 \mathrm{~b}-\mathrm{c}$ ). The longer holding time, results in the more martensite phases. The rapid cooling results in the incomplete carbon atoms diffusion and promoted the change of crystal structure from the FCC to BCT.
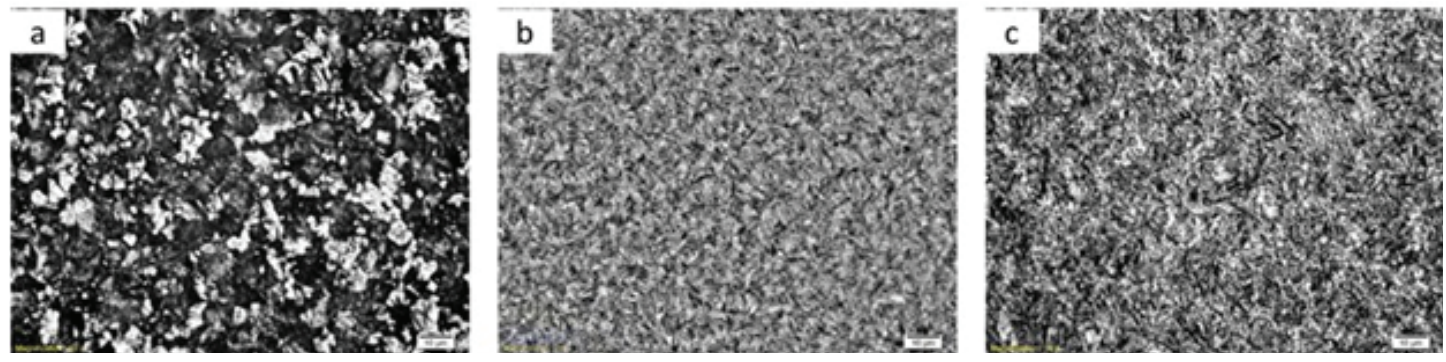

Figure 1: Micrographs of AISI 4340 steel (a) without treatment (b) Quenching $800{ }^{\circ} \mathrm{C}, 1 \mathrm{~h}$ (c) Quenching 800 ${ }^{\circ} \mathrm{C}, 2 \mathrm{~h}$.
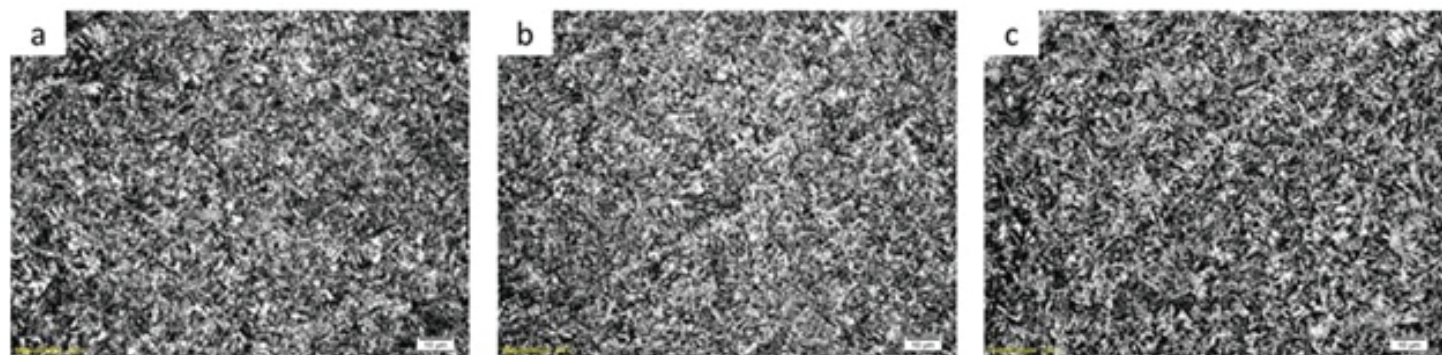

Figure 2: Micrographs of AISI 4340 steel after quenching at $800{ }^{\circ} \mathrm{C}$ for $2 \mathrm{~h}$ followed by tempering at 300 ${ }^{\circ} \mathrm{C}$ for (a) $2 \mathrm{~h}$ (b) $3 \mathrm{~h}$ (c) $4 \mathrm{~h}$.

Figure.2 (a-c) illustrates the microstructure of the samples after quenching at $800{ }^{\circ} \mathrm{C}$ for $2 \mathrm{~h}$ followed by tempering process at $300{ }^{\circ} \mathrm{C}$ for 2,3 , and $4 \mathrm{~h}$. All samples show the combination of ferrite and bainite phases. The tempering process promotes the transformation of martensite to bainite. Bainite is the intermediate phase before the formation of martensite which diverts the crystal structure from BCT to BCC. 


\subsection{Mechanical properties}

Figure. 3 shows the hardness of the samples with different heat treatment process. The figure describes that the quenching process is followed by the increasing in hardness due to the presence of martensite phase. Martensite phases with the crystal structure of BCT has the complicated atom formation and results in harder dislocation movement. The highest hardness occurs at the quenching process with holding time of $2 \mathrm{~h}$ (439.3 VHN). As shown in the Fig.3, the tempering process tends to reduce the hardness. The longer the holding time is, the lower the hardness of the tempered samples is. The phase transformation from martensite $(B C T)$ to bainit $(B C C)$ during the tempering process promoted the easier dislocation movement and resulted in the lower hardness.

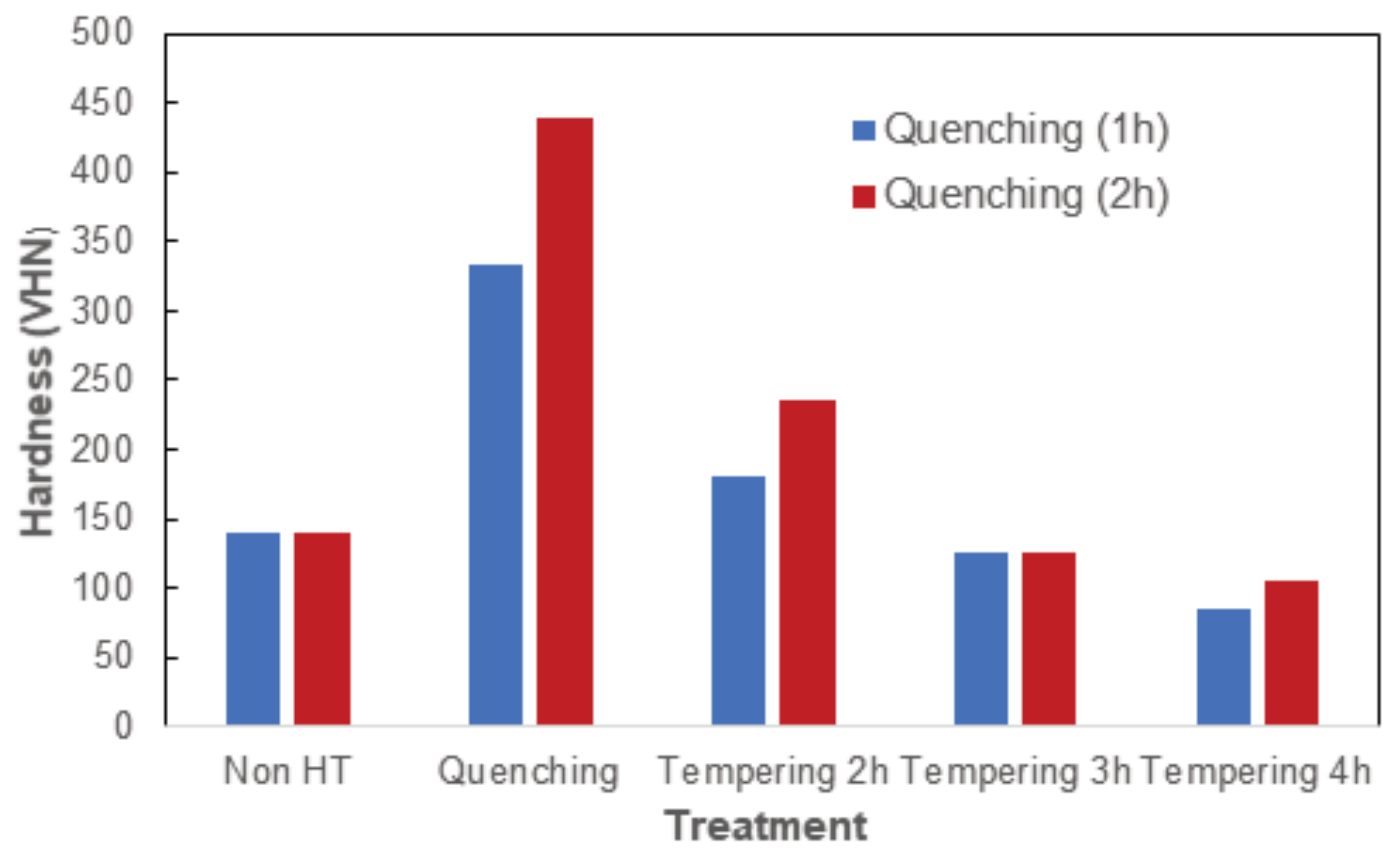

Figure 3: The Hardness change of AISI 4340 steel after quenching and tempering process.

Figure. 4 describes the toughness change of AISI 4340 steel after quenching and tempering processes. As shown at Figure.4 that the highest toughness occurs at the sample after quenching process at $800^{\circ} \mathrm{C}$ for $1 \mathrm{~h}$ followed by tempering at $300{ }^{\circ} \mathrm{C}$ for $3 \mathrm{~h}(144.9 \mathrm{~J} / \mathrm{mm} 2)$. On the other hand, lowest toughness occurs at the sample after quenching process at $800^{\circ} \mathrm{C}$ for $2 \mathrm{~h}(61.13 \mathrm{~J} / \mathrm{mm} 2)$. Quenching process promotes the formation of martensite phase with BCT crystal structure which has the highest hardness and in contrast the lowest toughness. In another hand, tempering process leads to formation of bainit phase which has the higher toughness than that of martensite phase 


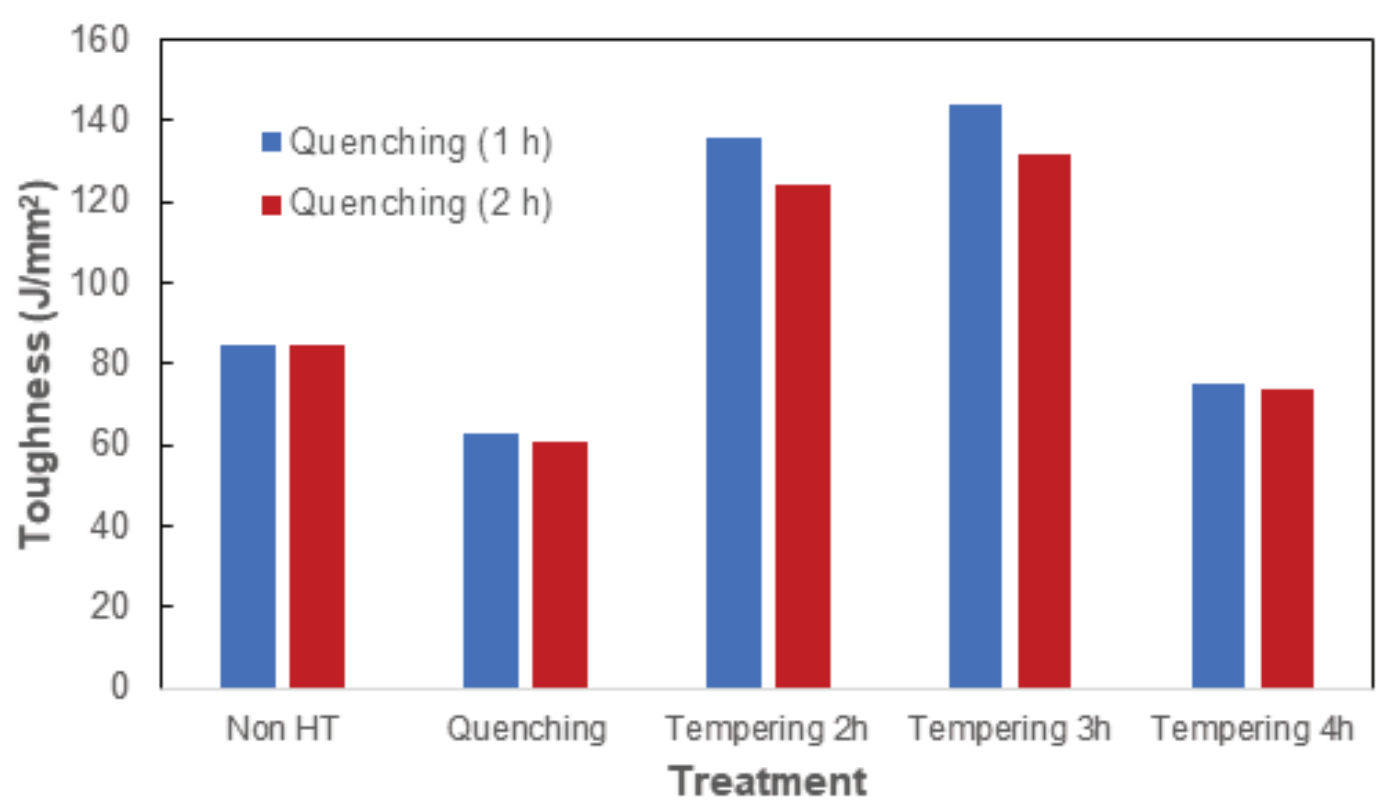

Figure 4: The toughness change of AISI 4340 steel after quenching and tempering process.

due to its BCC crystal structure. In tempering process, time is the crucial factor. As shown at Figure. 4 that, the toughness tends to decrease at the tempering process for $3 \mathrm{~h}$.

\section{Conclusion}

The results of the observation can be concluded as follows:

1. The quenching process changes the microstructure of AISI 4340 steel from ferrite and pearlite phases to be ferrite and martensite, in which the increase in quenching time from 1 to $2 \mathrm{~h}$ tends to increase the number of martensite.

2. The tempering process changes the microstructure of AISI 4340 steel from martensite to bainite, wherein the increase in holding time from 2,3 , and $4 \mathrm{~h}$ tends to decrease the number of bainite phases.

3. The addition of quenching holding time tends to increase the value of hardness, in which the time addition from 1 to $2 \mathrm{~h}$ results in the hardness increase about $31.4 \%$ from 334.12 to $439.3 \mathrm{VHN}$. On the other hand, the impact resistance value tends to decrease with an increase in holding time. The impact resistance value decreases about $3.7 \%$ from 63.41 to $61.14 \mathrm{~J} / \mathrm{mm}^{2}$.

4. The increase of tempering time results in a decrease of hardness, wherein the lowest hardness value of $85.48 \mathrm{VHN}$ is found at the sample with quenching time of $2 \mathrm{~h}$ and followed by tempering for $4 \mathrm{~h}$. 


\section{Funding}

This research was funded by Hibah Penelitian Unggulan Fakultas (PUF) 2018 from Universitas Negeri Jakarta.

\section{Conflict of Interest}

The authors have no conflict of interest to declare.

\section{References}

[1] Edmund Stump, W. \& Kasonde, M. (2012). Armour Steel, United Stated Patent No. US 2012/0174749 A1.

[2] Atapek, S.H. (2013). Development of a New Armour Steel and Its Ballistic Performance, Defence Sci. Journal, Vol. 63, No. 3, pp. 271-277.

[3] Atapek, S.H. (2012). Ballistic Impact Behaviour of Quenched and Tempered Steels" International Iron \& Steel Symposium, Karabuk, Turkey, pp.413-419.

[4] Atapek, S.H. and Karagoz, S. (2011). Ballistic Impact Behaviour of a Tempered Bainitic Steel Against 7.62 mm Armour Piercing Projectile, Defence Science Journal, Vol. 61, No. 1, pp. 81-87.

[5] Jamil, W.N.M., Aripin, M.A., Sajuri, Z., Abdullah, S., Omar, M.Z. (2016). Mechanical Properties and Microsturture of Steel Panel for Laminated Composites in Armour Vehicles, Int. J. of Automotive and mechanical Engineering, Vol. 13, No. 3, pp. 37423753.

[6] Sanusi, O.M. and Akindapo, J.O. (2015). Ballistic Performance of a Quenched and Tempered Stell Againts 7.62 mm Callibre Projectile, Nigerian J. of Tech., Vol. 34, No. 2, pp. 309-313.

[7] Williams, C.A. (2007). Vehicles Armour System, United States patent No.US 7,225,717 B2.

[8] Yanuar, P., Nugroho, S., Yurianto (2014). Karakteristik Baja Armour Hasil Proses Quenching dan Tempering, Prosiding SNST ke-5, Semarang.

[9] Rizal, Y. (2014). Analisa Pengaruh Media Quench Terhadap Kekuatan Tarik Baja AISI 1045, Jurnal APTEK, Vol. 6, No. 2.

[10] Bernetic, J., Vuherer, T., Marcetic, M., Vuruma, M., Jesenic, A. (2012). Experimental Research on New Grade of Steel Protective Material for Light Armored Vehicles, J. of Mech. Eng., Vol. 58, No. 6, pp. 416-421. 